[Regular Paper]

\title{
Calcination Temperature Effect on Supported Ruthenium Catalysts for Fischer-Tropsch Synthesis Reaction
}

\author{
Li Fan*, Michiharu Miyauchi, and Kaoru Fujimoto \\ Dept. of Applied Chemistry, School of Engineering, The University of Tokyo, \\ Hongo 7-3-1, Bunkyo-ku, Tokyo 113
}

(Received December 13, 1996)

\begin{abstract}
Adjustment of air calcination temperature can significantly change the metal dispersion of $\mathrm{Ru} / \mathrm{Al}_{2} \mathrm{O}_{3}$ catalyst and control the activity and selectivity of the Fischer-Tropsch synthesis. The reaction characteristics of the low-temperature-calcined catalysts were different from those of the hightemperature-calcined catalysts. The change in $\mathrm{CO}$ conversion by the catalysts calcined at different temperature took place in the range $200-250^{\circ} \mathrm{C}$. $n$-Hexane in supercritical state was used to effectively extract high-molecular-weight products in the catalyst bed and reactor, to attain a complete distribution of the products. The chain-grow th probability, as well as the olefin-to-paraffin ratio of the products was remarkably influenced by $\mathrm{Ru}$ dispersion. The water added to the synthesis gas promoted the chaingrowth probability and enhanced the olefin contents in the products. The strength of the bond between adsorbed $\mathrm{CO}$ and surface $\mathrm{Ru}$ atoms was greatly controlled by calcination temperature. Oxygenates were formed on low-temperature-calcined catalyst but hydrocarbons were formed only on high-temperaturecalcined catalyst in the ethylene-added Fischer-Tropsch reaction.
\end{abstract}

\section{Introduction}

In indirect conversion of fossil resources such as coal, natural gas or heavy oil into transportation fuels or chemicals, the Fischer-Tropsch (FT) synthesis that produces hydrocarbons via $\mathrm{CO}$ hydrogenation plays a key role. Rutheniumbased catalysts are known to be some of the most active FT catalysts, especially for production of long chain hydrocarbons from synthesis gas.

The effect of metal crystallite size (dispersion) in FT synthesis has been discussed in several previous studies for its great influence on the reactivity, selectivity and carbon chain-growth probability. Unfortunately, published results disagreed on the role and effect of the supported metal dispersion. There even exists an argument whether or not the FT reaction on supported $\mathrm{Ru}$ catalysts is structuresensitive. Also the existence of interaction between metal and support in FT reaction is debated.

Dalla Betta etal. observed that methanation activity of $\mathrm{Ru} / \mathrm{Al}_{2} \mathrm{O}_{3}$ catalysts increased with increasing dispersion. Later, they reported that hydrogenation of $\mathrm{CO}$ on $\mathrm{Ru}$ catalysts was a structure-insensitive reaction, and the initial rate of $\mathrm{CO}$ hydrogenation was independent of the

\footnotetext{
* To whom correspondence should be addressed.
}

diameter of Ru crystallite $(1.0-9.0 \mathrm{~nm})^{1), 2}$. Recently, Iglesia et al. also reported that FT synthesis on $\mathrm{Ru}$ catalysts was a structure-insensitive reaction. They also reported that the specific FT catalytic activity on $\mathrm{Ru}$ catalysts was not influenced by the size of the metal crystallite or by the nature of the metal oxide support ${ }^{3) \sim 7}$ ), at least for Ru crystallites larger than about $1.6 \mathrm{~nm}$. Kikuchi et al. reported that the specific rate of $\mathrm{CO}$ hydrogenation decreased by less than a factor of two when $\mathrm{Al}_{2} \mathrm{O}_{3}$ replaced $\mathrm{TiO}_{2}$ as a support for $\mathrm{Ru}$ crystallites (7-19\% Ru dispersion), while the chain-growth probability remained unchanged ${ }^{8)}$. It was reported that the turnover frequency of CO hydrogenation was similar on $\mathrm{Ru}(00 \mathrm{l})$ and $\mathrm{Ru}(1 \mathrm{ll})$ single crystals and it was close to that on supported $\mathrm{Ru}$ catalysts $^{9}$. Moreover, it was reported that alloy effects were consistent with the structureinsensitive pathways that required small ensembles of Ru surface atoms ${ }^{10)}, 11$.

In contrast, King observed that specific activities of supported $\mathrm{Ru}$ catalysts for methanation decreased from 0.16 to $0.01 \mathrm{~s}^{-1}$ as $\mathrm{Ru}$ dispersion increased from nearly zero ( $\mathrm{Ru}$ powder) to $64 \%$ $\left(\mathrm{Ru} / \mathrm{Al}_{2} \mathrm{O}_{3}\right)^{12)}{ }^{13)}$. Kellner and Bell reported King's similar observations of the relationship between dispersion and specific activity, as well as the existence of a support interaction with $\mathrm{Ru}$ 
metal 14),15). However they claimed that neither the chain-growth probability nor the olefin-toparaffin ratio was affected by $\mathrm{Ru}$ dispersion. In another study, the turnover rate were found to decrease markedly in the $\mathrm{Ru}$ dispersion range of 0 to $25 \%{ }^{16)}$. Smith and Everson also reported a 10 fold decrease in turnover rate as the dispersion of $0.5 \% \mathrm{Ru} / \mathrm{Al}_{2} \mathrm{O}_{3}$ eggshell catalyst increased from 16 to $78 \%{ }^{17)}$. In a study of support effects for $\mathrm{Ru}$ based FT catalysts ${ }^{18}$, similar conclusions were obtained. One of the present authors showed that supported $\mathrm{Ru}$ catalysts on a variety of carriers showed higher catalytic and higher chain-growth activities when they were calcined at higher temperatures ${ }^{19), 20)}$. Besides, Mieth and Schwarz prepared $\mathrm{Ru} / \mathrm{Al}_{2} \mathrm{O}_{3}$ catalysts from various $\mathrm{Ru}$ containing precursors and observed that for $\mathrm{CO}$ hydrogenation, turnover frequencies (TOFs) on larger Ru crystalline were higher ${ }^{21)}$.

It is considered that the contradictory observations observed in previous studies on the relationship between reaction performance (activity, selectivity, chain-growth probability) and catalyst structure ( $\mathrm{Ru}$ particle size, support identity, metalsupport interaction), should be due to low pressures and high temperatures that favored the methanation reaction in FT synthesis and that also favored extensive secondary reactions and deactivation. Moreover, high-molecular-weight hydrocarbons showed a tendency to remain inside the catalyst bed and catalyst pores, especially in the gas-phase reaction.

The objective of this study is to control Ru metal dispersion by altering the calcination temperature and to investigate the catalytic factors which affect activity, selectivity and chain-growth probability. Although the FT reaction was conducted in gas phase in the present study, supercritical phase hexane was employed after the reaction to extract the residual waxy hydrocarbons in the catalyst bed to evaluate the intrinsic capacity of the catalyst and to get an overall distribution of the products ${ }^{22) ~ 24)}$. We also reported here that added water and ethylene in the synthesis gas greatly affected the performance of FT reaction, in which aluminasupported ruthenium catalysts calcined at different temperatures were used.

\section{Experimental}

\section{1. Catalyst Preparation}

Alumina-supported $\mathrm{Ru}$ catalysts $(\mathrm{Ru}$ content: $2.0 \mathrm{wt} \%)$ were prepared by incipient wetness impregnation of $\gamma-\mathrm{Al}_{2} \mathrm{O}_{3}$ (Aerosil, C-type, $100 \mathrm{~m}^{2} / \mathrm{g}$ ) with an aqueous solution of $\mathrm{RuCl}_{3}$ (Koso Chemicals). In some reproducibility experiments, an- other type of $\gamma-\mathrm{Al}_{2} \mathrm{O}_{3}$ (JRC-ALO-4, Catalysis Society of Japan, $200 \mathrm{~m}^{2} / \mathrm{g}$ ) was used to eliminate the differentiation arising from other alumina supports. The impregnated samples were evacuated in a desiccator for $2 \mathrm{~h}$ and then dried by slow evaporation at room temperature. The catalyst precursors were dried at $120^{\circ} \mathrm{C}$ in air for $12 \mathrm{~h}$ and then calcined in air for $1 \mathrm{~h}$ at specified temperatures. Only ruthenium oxide was detected by XRD for ruthenium species on these catalyst precursors.

After sieving to the desired pellet sizes (6080 mesh), all catalysts were reduced in flowing hydrogen at $150^{\circ} \mathrm{C}$ for $1 \mathrm{~h}, 300^{\circ} \mathrm{C}$ for $1 \mathrm{~h}$, and $400^{\circ} \mathrm{C}$ for $2 \mathrm{~h}$ in series and then cooled to room temperature to be passivated with a diluted air stream. The catalysts were reduced in situ again at $400^{\circ} \mathrm{C}$ for $1 \mathrm{~h}$ before use. The catalysts at this stage were washed with hot water and the washing solution was analyzed by ion chromatography. Chlorine was neither detected by it nor by Energy Dispersive Spectroscopy (EDS) analysis. Induced Coupling Plasma (ICP) was employed to determine the Ru content in the catalyst after calcination. But it was found unchanged (1.99 wt\%) for the $120^{\circ} \mathrm{C}$ calcined catalyst; however, it was markedly decreased $(1.95 \mathrm{wt} \%)$ for the $400^{\circ} \mathrm{C}$-calcined catalyst, probably because of the sublimation of ruthenium oxide at higher temperatures of calcination. In order to prevent the formation of hot spots during the reaction, the catalyst was diluted to the same volume with quartz beads.

\section{2. Reaction, Extraction and Analysis}

The Fischer-Tropsch synthesis reaction was performed in a high pressure flow system with a fixed bed reactor in which gas phase, liquid phase, and supercritical phase reactions could all be performed. The details of the reaction apparatus and procedure have been reported elsewhere ${ }^{22)}$. The catalyst was reduced in hydrogen at $400^{\circ} \mathrm{C}$ for $\mathrm{l} \mathrm{h}$, cooled to the reaction temperature and then exposed to the feed gas. All kinetic data were obtained after $4 \mathrm{~h}$ on stream to ensure steady-state conditions. In the reaction using the water-added synthesis gas, the water was injected quantitatively with a high-pressure microfeeder and mixed with the synthesis gas in a vaporizer which was set upstream of the catalyst bed. The stoichiometric ratio of the feed gas was maintained at $\mathrm{H}_{2} / \mathrm{CO}=2$.

The supercritical fluid (hexane at $45 \mathrm{~atm}$ and $240^{\circ} \mathrm{C}$ ) was introduced into the reactor with a high pressure pump to extract the residual waxy products in the catalyst bed after the gas-phase FT reaction. The extracted products and supercritical fluid were collected in an ice trap downstream.

Gaseous compounds were analyzed with an on- 
line gas chromatograph. $\mathrm{CO}, \mathrm{CH}_{4}$, and $\mathrm{CO}_{2}$ were analyzed by using an activated charcoal column with a thermal conductivity detector. Light hydrocarbons were analyzed with a Porapak-Q column with a flame ionization detector. Effluent hydrocarbons were analyzed with Silicone SE-52 and Dexil-300 GC columns each equipped with a flame ionization detector. Some of the high molecular weight hydrocarbons were analyzed by high-temperature gel permeation chromatograph (Walters, 860/V2.2).

Serving as internal standard, 3\% inert argon gas was included in the feed gas. The chain-growth probability ( $\alpha$ value) of the product was defined by the Anderson-Schulz-Flory plot of the total products including those extracted.

\section{3. Catalyst Characterization}

The ruthenium dispersion, defined as the fraction of metal atoms residing on the surface of supported metal crystallites, was determined by means of hydrogen chemisorption. Chemisorption was performed at room temperature by using a flow-through cell connected to a glass vacuum system. Passivated catalyst samples were first activated in flowing hydrogen in situ at $400^{\circ} \mathrm{C}$ for $1 \mathrm{~h}$, then evacuated at $450^{\circ} \mathrm{C}$ for $2 \mathrm{~h}$. Chemisorption of hydrogen or that of $\mathrm{CO}$ was determined as the difference between the first isotherm and the second isotherm, in which the second isotherm was measured following evacuation for $30 \mathrm{~min}$ at room temperature after the measurement of the first isotherm. The metal dispersion was calculated assuming that one hydrogen atom was chemisorbed on one surface ruthenium atom. The particle size of ruthenium metal was calculated from equation $D=1 \mathrm{l} /(\mathrm{H} / \mathrm{Ru})^{25)}$, where $D$ is the diameter in angstroms and $\mathrm{H} / \mathrm{Ru}$ is the ratio of the number of hydrogen atoms adsorbed divided by the total number of $\mathrm{Ru}$ atoms in the catalyst.

Experiments on Temperature Programmed Reaction (TPR) of $\mathrm{CO}$ were conducted in hydrogen flow at the rate of $400^{\circ} \mathrm{C} / \mathrm{h}$ after removing the physically adsorbed CO. Such products as $\mathrm{CH}_{4}$, $\mathrm{CO}, \mathrm{CO}_{2}$ were analyzed by gas chromatograph equipped with a methanator and a flame ionization detector. Experiments on Temperature Programmed Desorption (TPD) was conducted similarly as those of TPR except for helium, carrier gas, and for the desorbed products, $\mathrm{CO}$ and $\mathrm{CO}_{2}$. The desorbed products were analyzed by a thermal conductivity detector.

High-pressure infrared spectroscopy was recorded on JASCO A-3 infrared spectrometer with a home-made high-pressure IR cell.

X-Ray diffraction (XRD) measurements were performed with a Rigaku Rotaflex instrument using Cu K $\alpha$ irradiation ( 40 kV, 100 mA). Scherrer equation was used to determine the average size of Ru particle. Transmission electronic microscopy (TEM) (JEOL, JEM-2010, $200 \mathrm{kV}$ ) was also used to observe the $\mathrm{Ru}$ particles.

\section{Results and Discussion}

\section{1. Reaction Characteristics of $\mathrm{Ru} / \mathrm{Al}_{2} \mathrm{O}_{3}$ Cal- cined at Different Temperatures}

\section{1. 1. Catalytic Activity}

Catalytic activities of alumina-supported ruthenium catalysts calcined at 120, 200, 250, 300, and $400^{\circ} \mathrm{C}$, respectively, are shown in Fig. 1. The reaction temperature was $240^{\circ} \mathrm{C}$. Generally, the activity was enhanced with increasing calcination temperature but an activity gap appeared at $200^{\circ} \mathrm{C}$ and $250^{\circ} \mathrm{C}$. To ensure reproducibility, another type of $\gamma-\mathrm{Al}_{2} \mathrm{O}_{3}$ (JRC-ALO-4, Catalysis Society of Japan) instead of aerosil alumina was used to prepare alumina-supported Ru catalyst. A gap in $\mathrm{CO}$ conversion was observed also at calcination temperature around $200-250^{\circ} \mathrm{C}$, when the reaction temperature was either $240^{\circ} \mathrm{C}$ or $270^{\circ} \mathrm{C}$, as shown in Fig. 2. It was referred that this kind of catalytic activity change was independent of the type of alumina support or of the reaction temperature, at least under the reaction conditions involved.

The results of hydrogen chemisorption, along with X-ray diffraction and transmission electronic microscopy data, are compared in Table 1 . From the dispersion of $\mathrm{Ru}$ metal, it was found that the catalysts calcined at lower temperature had a larger dispersion. The turnover frequencies (TOFs) of various catalysts are also given in Fig. 1. The catalysts whose calcination temperature varied from 120 to $250^{\circ} \mathrm{C}$ exhibit similar, low TOF values. Catalysts calcined at $400^{\circ} \mathrm{C}$ showed remarkably large TOF values. But those calcined at lower temperature showed low TOF values even if high metal dispersions existed in these catalysts. However for the catalysts calcined at higher temperatures, the metal dispersions were low in spite of their high TOF values. It proved that $\mathrm{Ru}$ crystallite size remarkably influenced the intrinsic activity of FT reactions.

Another important fact for the catalysts calcined at different temperatures is the change in the chaingrowth activity as shown in Fig. 3. The chaingrowth probability of the catalyst calcined at $120^{\circ} \mathrm{C}$ or at $200^{\circ} \mathrm{C}$ was low and nearly the same (0.84 and 0.86). On the other hand, catalysts calcined at $250^{\circ} \mathrm{C}, 300^{\circ} \mathrm{C}$ or $400^{\circ} \mathrm{C}$ displayed another pattern of product distribution, that is, they included more high-molecular-weight products; also the chain-growth probabilities of 


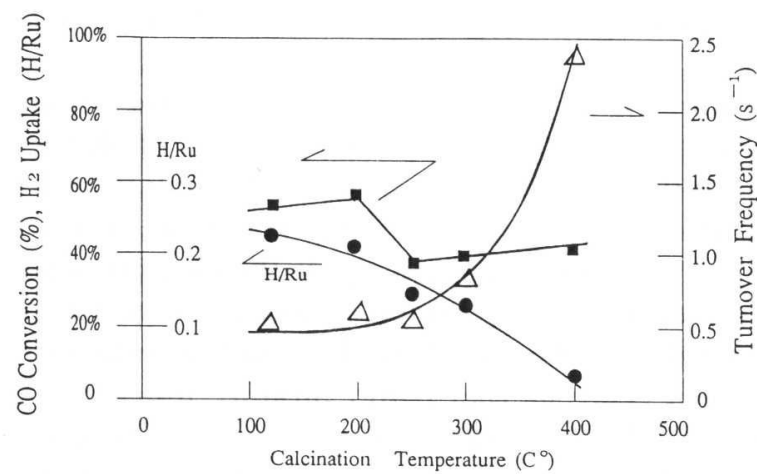

$\mathrm{Ru} / \mathrm{Al}_{2} \mathrm{O}_{3}$ (Aerosil), $2 \mathrm{wt} \%, 2 \mathrm{~atm}, 240^{\circ} \mathrm{C}, \mathrm{H}_{2} / \mathrm{CO}=2 / 1$, $W / F=4 \mathrm{~g} \cdot \mathrm{h} / \mathrm{mol}$.

Fig. I The Relationship among CO Conversion, $\mathrm{H}_{2}$ Uptake, Turnover Frequency, and Catalyst Calcination Temperature

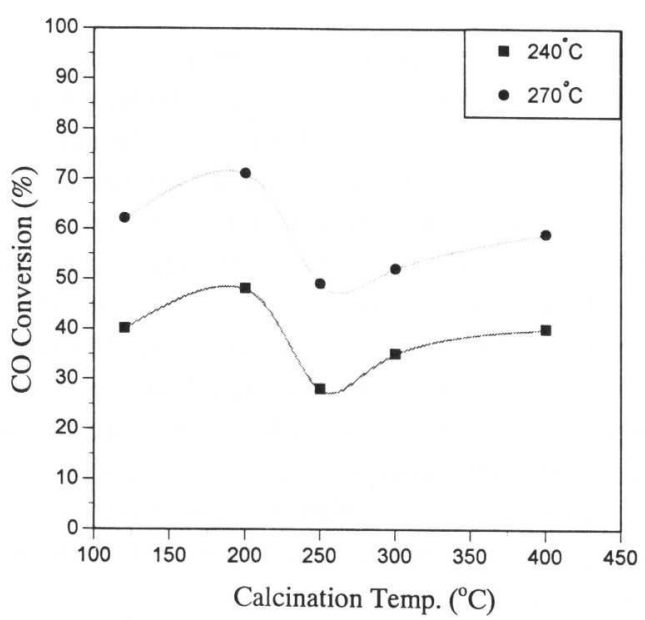

$\mathrm{Ru} / \mathrm{Al}_{2} \mathrm{O}_{3}(\mathrm{JRC}-\mathrm{ALO}-4), 2 \mathrm{wt} \%, 2 \mathrm{~atm}, \mathrm{H}_{2} / \mathrm{CO}=2 / \mathrm{l}$, $W / F=2 \mathrm{~g} \cdot \mathrm{h} / \mathrm{mol}$.

Fig. 2 The Relationship among CO Conversion and Catalyst Calcination Temperature

Tabel 1 Particle Size of Supported Ru Crystalline

\begin{tabular}{lllllll}
\hline $\begin{array}{c}\text { Calcination temp. } \\
{\left[{ }^{\circ} \mathrm{C}\right]}\end{array}$ & 120 & 200 & 250 & 300 & 400 \\
\hline $\mathrm{H} / \mathrm{Ru}$ & & 0.24 & 0.22 & 0.16 & 0.14 & 0.04 \\
$D=11 /(\mathrm{H} / \mathrm{Ru})$ & {$[\AA]$} & 46 & 50 & 68 & 79 & 275 \\
$\mathrm{XRD}$ & {$[\AA]$} & $\mathrm{nd}^{\mathrm{a})}$ & $\mathrm{nd}$ & $\mathrm{nd}$ & 144 & 360 \\
$\mathrm{TEM}$ & {$[\AA]$} & 55 & 76 & 88 & 115 & 310 \\
\hline
\end{tabular}

a) Not detected in XRD data.

these catalysts were higher (0.93-0.96). It should be noted that the products here included not only the effluent products but also the extracted products from inside the catalyst bed with a supercritical fluid. Chain-growth probability is greatly controlled by $\mathrm{Ru}$ crystallite size, as predicted by Nijs and Jacobs ${ }^{26)}$.

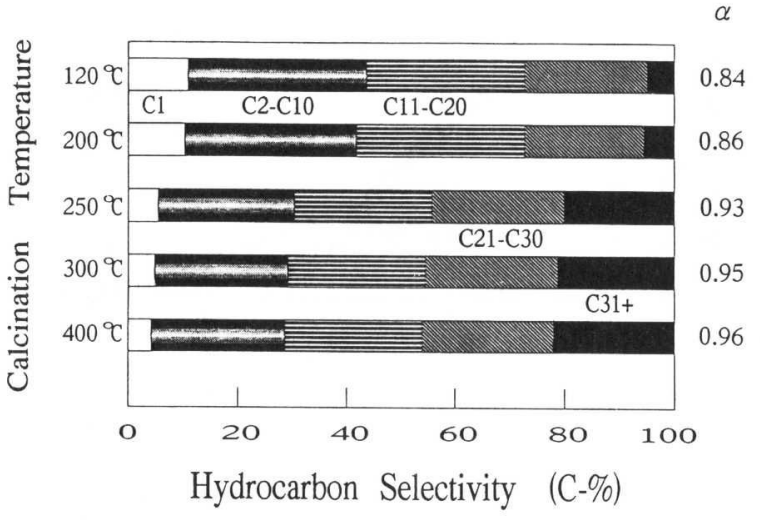

The same reaction condition as in Fig. 1.

Fig. 3 Hydrocarbon Product Distributions of Various Catalyst

The reason for the remarkable changes in activity and selectivity of the catalyst calcined between $200^{\circ} \mathrm{C}$ and $250^{\circ} \mathrm{C}$ is not clear, because the compromising effect of TOF change and dispersion variation derived from different calcination temperatures seem unable to elucidate all details clearly. Presumably, the Ru particles on the catalyst calcined at $200^{\circ} \mathrm{C}$ and $250^{\circ} \mathrm{C}$ in air had a special crystalline configuration to influence the $\mathrm{CO}$ adsorption state. It was estimated that $\mathrm{Ru}$ atoms on the crystalline faces were more active than those at the edges or corners ${ }^{14), 27) ~ 30)}$. Similarly, it can be expected that high-temperature-calcined alumina-supported ruthenium possessed a different crystallographic plane, where the $\mathrm{CO}$ adsorbed could be decomposed more efficiently, leading to a high chain-growth probability and a gap in the relationship between CO conversion and catalyst calcination temperature. We also agreed that the SMSI effect did not appear to influence the catalytic rates here because of the exposure to the water produced in the FT synthesis? ${ }^{7}$.

Many of the contradicting reports on the effects of dispersion and supports may reflect the differences in operating conditions, that can alter the identity and structural requirements of the ratelimiting step. Previously reported effects on dispersion and supports on $\mathrm{Ru}$ catalysts were obtained under the conditions that favored the formation of light products.

\section{1.2. Selectivity and Carbon-chain Growth Probability}

Heavy hydrocarbon products often accumulate inside the catalyst pores in common gas-phase FT reactions, especially in heavy hydrocarbon synthesis. The present authors have developed a 

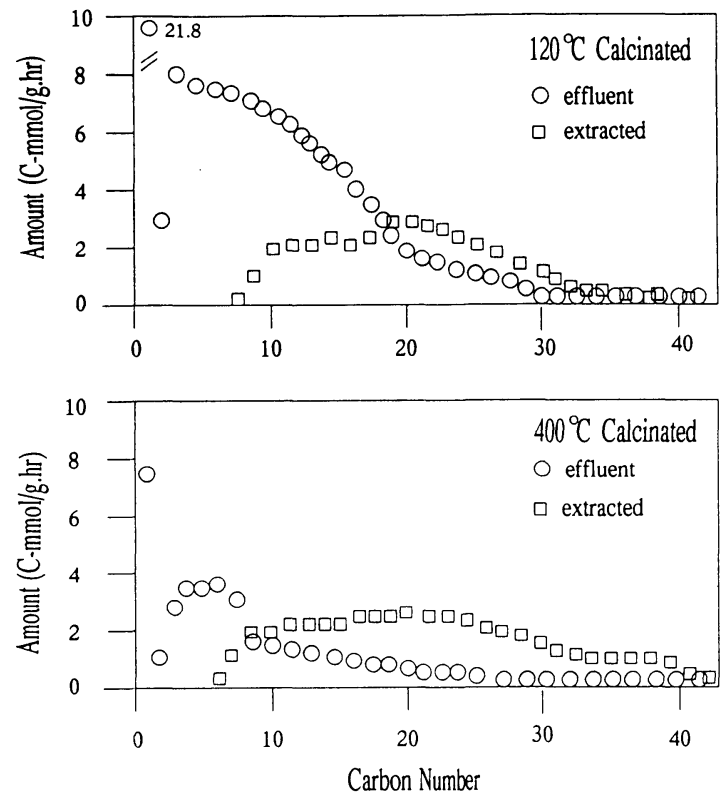

Supercritical fluid: $n$-hexane, $240^{\circ} \mathrm{C}, 45 \mathrm{~atm}$. Extraction time: $1 \mathrm{~h}$.

Fig. 4 Comparison of Distribution of Effluent and Extracted Products

supercritical phase Fischer-Tropsch synthesis reaction to suppress deactivation of the catalyst22 244 . The quick mass transfer and heat transfer in the supercritical-phase FT reaction led to effective extraction of waxy products in situ and prevented secondary reactions of olefins. A satisfactory product distribution by gas-phase FT reaction could be attained if the residual waxy products inside the catalyst pores and the catalyst bed were extracted by supercritical fluid after gasphase reaction. Figure 4 shows the distribution of effluent and extracted products for the catalyst calcined at $120^{\circ} \mathrm{C}$ or at $400^{\circ} \mathrm{C}$. It should be noted that extraction of the residual hydrocarbons was implemented after the reaction. Standard reaction time was $10 \mathrm{~h}$. The amount of residual hydrocarbons per hour was determined by dividing the total extracted hydrocarbons by reaction time. It is astonishing that for the catalyst calcined at $400^{\circ} \mathrm{C}$ (Table 2), more than half of the total hydrocarbon products (carbon base) remained inside the catalyst bed instead of flowing out of the reactor. The total product distribution of the $400^{\circ} \mathrm{C}$-calcined catalyst was a flat distribution and was likely to produce high-molecular-weight hydrocarbons, and as a result, the chain-growth probability was as high as 0.96 ; however the chaingrowth probability of $120^{\circ} \mathrm{C}$-calcined catalyst was lower $(0.86)$ under the same conditions. Thus, it could be concluded that the carbon-chain growth probability was higher on larger ruthenium particles.

Some investigators advocated that the chaingrowth probability was independent of the $\mathrm{Ru}$ crystalline size in the supported Ru catalyst for FT synthesis ${ }^{1 \sim 11)}$. Based on the fact that so much waxy products remained inside the catalyst pores, the chain-growth probability should be calculated carefully in the gas-phase FT reaction especially for $\mathrm{Ru}$ catalysts that could produce much heavy hydrocarbons. Full "spectra" of total products are necessary to determine the intrinsic chaingrowth probability. In fact, high-temperature gel permeation chromatography analysis showed that the average molecular weight (weight average) of the solid-state extracted hydrocarbons (prepared by evaporation of the extracted products and solvent in vacuum) formed on the $120^{\circ} \mathrm{C}$-calcined catalyst was 570 while that on the $400^{\circ} \mathrm{C}$-calcined catalyst was 1000 .

Both $400^{\circ} \mathrm{C}$-calcined and $120^{\circ} \mathrm{C}$-calcined catalysts showed stable activity during $10 \mathrm{~h}$ of reaction. As mentioned above, all data were obtained after $4 \mathrm{~h}$ of reaction from the start to ensure a steady state. It was found that $120^{\circ} \mathrm{C}$-calcined catalyst reached the steady state after $4 \mathrm{~h}$, while the $400^{\circ} \mathrm{C}$ calcined catalyst attained it after $3 \mathrm{~h}$. Steady state requires the formation of waxy liquid inside the catalyst micropores and the equilibrium between desorption of hydrocarbons from the catalyst inner surface and diffusion of syngas as well as that of the hydrocarbons. As $400^{\circ} \mathrm{C}$-calcined catalyst produced more waxy hydrocarbons, it could attain a steady state more rapidly.

Figure 5 indicates a difference in the olefin contents of the products of $120^{\circ} \mathrm{C}$ - and $400^{\circ} \mathrm{C}$-calcined catalysts, in which more olefins were found in the $400^{\circ} \mathrm{C}$-calcined catalyst. However, the difference was not changed by reaction period.

Olefins which are considered primary products in FT synthesis can be readsorbed onto the Ru sites to undergo such secondary reactions as hydrogenation to paraffin, chain propagation, isomerization, and others. The above difference in reaction performances of the catalysts calcined at different temperatures could be attributed to several reasons: at first, for the $120^{\circ} \mathrm{C}$-calcined catalyst, $\mathrm{Ru}$ particles are small, so the adsorbed $\mathrm{CO}$ would be difficult to be decomposed, as will be explained below. Consequently, the active carbide produced from the decomposition of adsorbed $\mathrm{CO}$ was little and the adsorbed hydrogen concentration on the catalyst surface was relatively higher. Olefins could be hydrogenated more easily than would be involved in a chain-growth reaction. Secondly, it seems that small Ru par- 


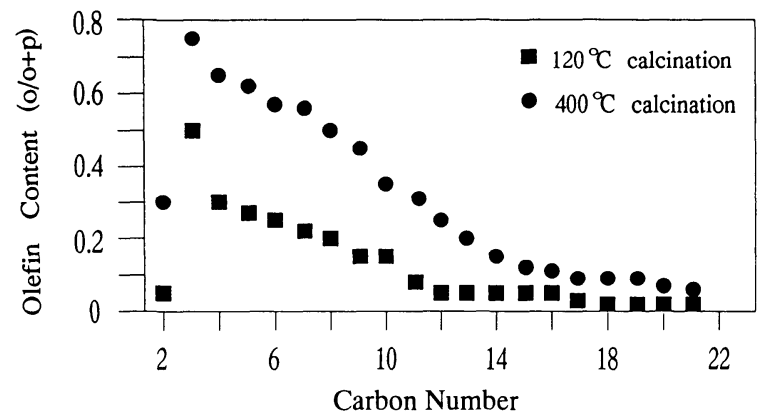

Fig. 5 Olefin Content in FT Reaction Product of $120^{\circ} \mathrm{C}$ - and $400^{\circ} \mathrm{C}$-Calcined Catalysts

Tabel 2 Reaction Behavior of Catalyst Calcined at Different Temperatures

\begin{tabular}{lccc} 
Calcination temp. & {$\left[{ }^{\circ} \mathrm{C}\right]$} & 120 & 400 \\
CO conversion & {$[\%]$} & 55 & 40 \\
Metal dispersion $(\mathrm{H} / \mathrm{Ru})$ & & 0.24 & 0.04 \\
Turnover frequency & {$\left[\mathrm{s}^{-1}\right]$} & 0.53 & 2.38 \\
Chain-growth probability & & 0.84 & 0.96 \\
Residual ratio & & 0.31 & 0.55 \\
Propene/(Propane+Propene) & 0.51 & 0.77 \\
$\mathrm{CO}_{2}$ formation rate $\quad[\mathrm{mmol} / \mathrm{g} \cdot \mathrm{h}]$ & 0.26 & 0.05 \\
\hline
\end{tabular}

a) The ratio of extracted hydrocarbons to total hydrocarbons. Reaction conditions: $\mathrm{Ru} / \gamma-\mathrm{Al}_{2} \mathrm{O}_{3}, 2 \mathrm{wt} \%$, Gas phase, $240^{\circ} \mathrm{C}$, $21 \mathrm{~atm}, \mathrm{H}_{2} / \mathrm{CO}=2, W / F=4 \mathrm{~g} \cdot \mathrm{h} / \mathrm{mol}$, Particle size: $60-80$ mesh.

ticles could enhance the decomposition of $\mathrm{H}_{2} \mathrm{O}$ more effectively and lead to a high surface hydrogen concentration ${ }^{31)}$. Lastly, for the catalyst treated at $120^{\circ} \mathrm{C}$, the primary olefins could be readsorbed more readily onto the surface-active $\mathrm{Ru}$ sites to undergo secondary hydrogenation while being transported inside the catalyst pellets, because of its high surface $\mathrm{Ru}$ site concentration ${ }^{22)}$.

It is interesting to find that the rate of formation of carbon dioxide was also different for $120^{\circ} \mathrm{C}$ and $400^{\circ} \mathrm{C}$ calcined catalysts as shown in Table 2 . The rate of $\mathrm{CO}_{2}$ formation on $120^{\circ} \mathrm{C}$-calcined catalyst was about five times higher than that on $400^{\circ} \mathrm{C}$-calcined catalyst.

The slow rate of $\mathrm{CO}_{2}$ formation on larger ruthenium particles in the FT synthesis indicated that the surface oxygen, product $\mathrm{CO}$ dissociation, reacted with surface hydrogen kinetically more rapidly than with the $\mathrm{CO}$ adsorbed on the surface. Another possibility for $\mathrm{CO}_{2}$ formation is the water gas shift reaction on the surface by the FT byproduct water and $\mathrm{CO}$ :

$$
\mathrm{COs}+(\mathrm{OH}) \mathrm{s} \rightarrow\left(\mathrm{CO}_{2}\right) \mathrm{s}+\mathrm{Hs}
$$

Surface species are indicated by s. The low possibility of this reaction occurring on $400^{\circ} \mathrm{C}$ - calcined catalyst should be attributed to the low concentration of surface hydroxyl or to the low ability of water dissociation on large $\mathrm{Ru}$ particles.

Over highly dispersed $\mathrm{Ru}$, some of the reasons for large quantities of $\mathrm{CO}_{2}$ formed can be the rapid removal of surface oxygen by $\mathrm{CO}$ instead of by hydrogen and the occurrence of effective surface water gas shift reaction. In this case, it is suggested that highly dispersed ruthenium has effective sites to cleave $\mathrm{H}_{2} \mathrm{O}^{31}$.

\section{2. Effect of Calcination Temperature on Cata- lytic Features}

\section{2. 1. Effect of Added Water}

Water is a byproduct in the Fischer-Tropsch synthesis. Water was provided as a component in the feed gas to enhance the partial pressure of hydrogen by water gas shift reaction. In order to fix the partial pressure ratio of $\mathrm{CO}$ and $\mathrm{H}_{2}$, nitrogen gas was used as the balancing gas to compensate the pressure change resulted from water gas. It was found that the rate of $\mathrm{CO}_{2}$ formation increased tremendously in the wateradded FT reaction. The main reason for this was the water gas shift reaction. Figure 6 exhibits the relationship between the hydrocarbon yield of the FT reaction and the partial pressure of water of its feed gas. It was interesting to note that, for the catalyst calcined at $120^{\circ} \mathrm{C}$, the hydrocarbon yield increased when the water gas partial pressure was increased, but when it became above $3.4 \mathrm{~atm}$, the hydrocarbon yield was increased but only to some extent. As opposed to this, the hydrocarbon yield was decreased slightly when the water gas partial pressure increased for the catalyst calcined at $400^{\circ} \mathrm{C}$.

The simulation model of $\mathrm{FT}$ reaction kinetics showed that both limited diffusion of $\mathrm{CO}$ and limited transportation olefin readsorption could affect the activity and selectivity of FT reaction process $\left.{ }^{4)}, 7\right), 22$ ). For the catalyst calcined at $120^{\circ} \mathrm{C}$, which had higher $\mathrm{Ru}$ surface atom density, the limited diffusion behavior of reactant $\mathrm{CO}$ had greater impact on the activity and selectivity of FT reaction than the transportation of primary olefins. As the $120^{\circ} \mathrm{C}$-calcined catalyst had a larger surface of $\mathrm{Ru}$ site because of its high $\mathrm{Ru}$ dispersion, the $\mathrm{CO}$ concentration inside the pellet dropped more sharply than that inside the $400^{\circ} \mathrm{C}$ calcined catalyst pellet ${ }^{32}$. The $\mathrm{CO}$ diffusion restriction could be released and the intrapellet $\mathrm{CO}$ concentration could be enhanced when the water partial pressure was increased, because the dissolved water selectively increased the diffusivity of the diffusion-limited reactant $\mathrm{CO}$, due to the affinity between them. It is referred that $\mathrm{CO}$ concentration inside $120^{\circ} \mathrm{C}$-calcined catalyst increased more remarkably. 


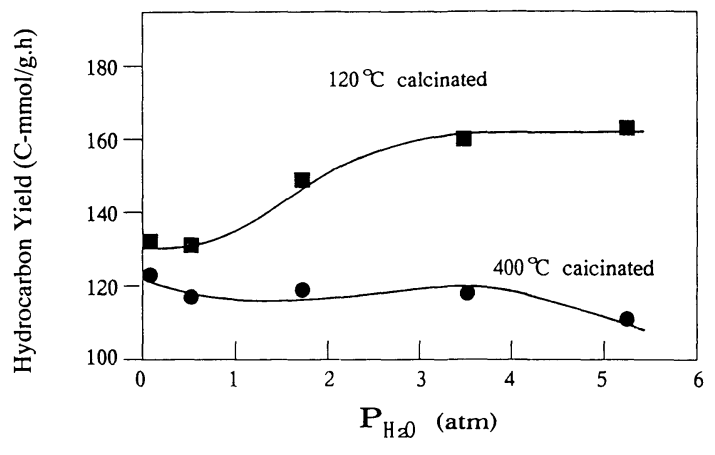

$\mathrm{Ru} / \mathrm{Al}_{2} \mathrm{O}_{3}$ (Aerosil), $2 \mathrm{wt} \%, 2 \mathrm{latm}, 240^{\circ} \mathrm{C}, \mathrm{H}_{2} / \mathrm{CO}=2 / \mathrm{l}$, $W / F=2 \mathrm{~g} \cdot \mathrm{h} / \mathrm{mol}$.

$P_{\mathrm{CO}}=5.1 \mathrm{~atm}, P_{\mathrm{H}_{2}}=10.5 \mathrm{~atm}, P_{\mathrm{H}_{2} \mathrm{O}}+P_{\mathrm{N}_{2}}=5.4 \mathrm{~atm}$.

Fig. 6 Effect of Added Water in the Feed Gas: Water Partial Pressure vs. Hydrocarbon Yield

In contrast, the removal of the hydrocarbon products played a more obvious role than the arrival of reactant $\mathrm{CO}$ for the $400^{\circ} \mathrm{C}$-calcined catalyst which had a lower surface $\mathrm{Ru}$ atom concentration. Increased water partial pressure had but slight influence on the transportation of primary olefins due to the weak affinity between water and hydrocarbons. The $400^{\circ} \mathrm{C}$-calcined catalyst produced more high-molecular-weight and olefinic hydrocarbons in greater yields, as exhibited in Figs. 3-5. The CO in $400^{\circ} \mathrm{C}$-calcined catalyst could not diffuse rapidly through the waxy membrane to reach the $\mathrm{Ru}$ surface ${ }^{22), 23)}$, for gasphase FT reaction. Meanwhile olefins adsorbed more strongly than paraffins onto the $\mathrm{Ru}$ surface, to hinder the mass transfer efficiency $\left.\left.{ }^{3)}, 4\right), 19\right)$. Consequently, the increased intrapellet $\mathrm{CO}$ concentration could not contribute effectively to hydrocarbon formation for $400^{\circ} \mathrm{C}$-calcined catalyst.

Moreover, hydrocarbon distributions under various water partial pressures for $120^{\circ} \mathrm{C}$ or for $400^{\circ} \mathrm{C}$ calcined catalyst are shown in Fig. 7. On either of the two catalysts, the proportion of light hydrocarbons in the total product decreased and that of heavy hydrocarbons increased when the partial pressure of water increased, but methane formation was restrained especially by increasing the water vapor partial pressure. In general, the $400^{\circ} \mathrm{C}$-calcined catalyst could produce more heavy hydrocarbons, in other words, exhibited higher chain-growth probability than the $120^{\circ} \mathrm{C}$-calcined catalyst, even if water gas was added to the feed gas.

Several reasons for the above observations can be offered: when the partial pressure of water was increased on the inner surface of the catalyst pellet, water could suppress the desorption of hydrocarbon products and could inhibit secondary
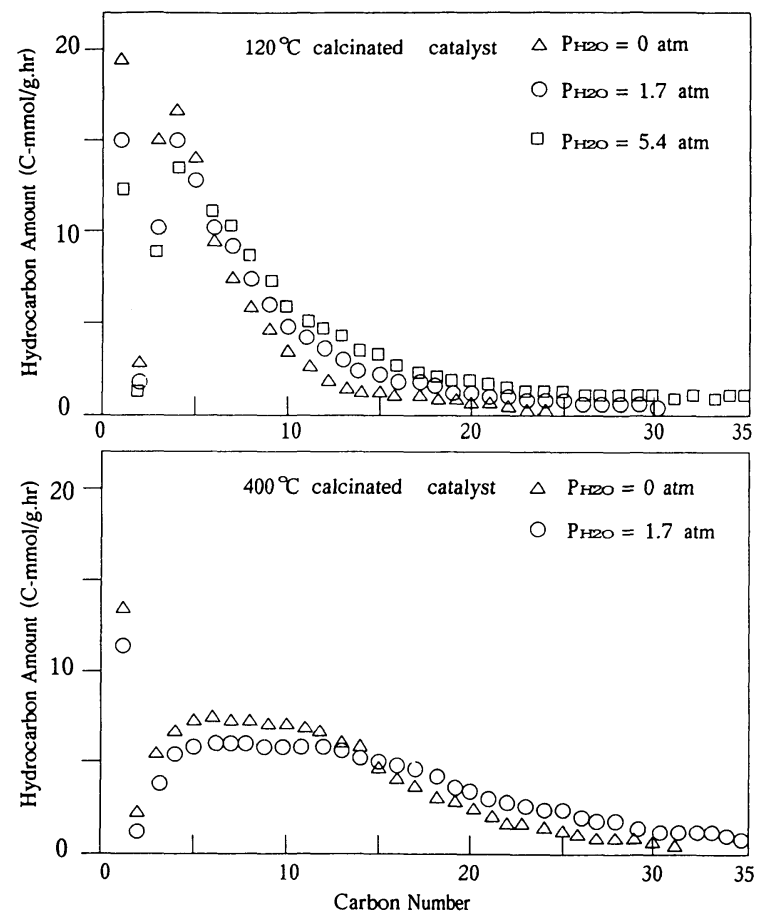

The same reaction condition as in Fig. 6.

Fig. 7 Product Distribution of Water-added FischerTropsch Reaction under Various Water Partial Pressures

hydrogenation of the olefins because of their low affinity to water, as Nijs and Jacobs had observed that water enhanced the readsorption of some light olefins on $\mathrm{Ru}$ catalysts ${ }^{33)}$. As a result, the residence time of the primary hydrocarbon products was extended and the chain-growth probability was enhanced due to the readsorption of the primary products. Another reason refers to the adsorption of water onto the metal surface sites that suppressed the adsorption of hydrogen onto it to decrease the possibility of carbon chain growth termination. Another possible reason is that water was capable of increasing the diffusivity of $\mathrm{CO}$ molecules inside catalyst pellets and the concentration of $\mathrm{CO}$ near the chain growth site was enhanced, relatively the partial pressure of hydrogen decreased. The hydrogen-lack circumstances were favorable to carbon chain propagation because it would make carbon chain termination probability decreased. We found that the olefin content in the water-cofed $\mathrm{FT}$ reaction products increased remarkably. This fact is interesting because the partial pressure of hydrogen was increased and it was higher in the water-fed FT reaction compared with the nonfed FT reaction because of the water gas shift reaction, even if the activity was slightly decreased when water was 
Tabel 3 Effect of Ethylene Addition to Feed Gas

\begin{tabular}{|c|c|c|c|c|}
\hline \multirow{2}{*}{$\frac{\text { Calcination temp. } \quad\left[{ }^{\circ} \mathrm{C}\right]}{\mathrm{C}_{2} \mathrm{H}_{4} \text { feed }[\mathrm{mmol} / \mathrm{g} \cdot \mathrm{h}]}$} & \multicolumn{2}{|c|}{120} & \multicolumn{2}{|c|}{400} \\
\hline & 0 & 16.8 & 0 & 16.8 \\
\hline $\mathrm{CH}_{4}$ yield $[\mathrm{mmol} / \mathrm{g} \cdot \mathrm{h}]$ & 1.48 & 0.71 & 0.41 & 0.32 \\
\hline $\mathrm{C}_{2} \mathrm{H}_{6}$ yield $[\mathrm{mmol} / \mathrm{g} \cdot \mathrm{h}]$ & 0.05 & 9.46 & 0.01 & 16.85 \\
\hline $\mathrm{C}_{2} \mathrm{H}_{4}$ yield $[\mathrm{mmol} / \mathrm{g} \cdot \mathrm{h}]$ & 0.02 & $3.09^{\mathrm{a})}$ & 0.01 & $0.84^{\text {a) }}$ \\
\hline $\mathrm{C}_{3} \mathrm{H}_{8}$ yield $[\mathrm{mmol} / \mathrm{g} \cdot \mathrm{h}]$ & 0.05 & 0.08 & 0.01 & 0.02 \\
\hline $\mathrm{C}_{3} \mathrm{H}_{6}$ yield $[\mathrm{mmol} / \mathrm{g} \cdot \mathrm{h}]$ & 0.15 & 0.27 & 0.03 & 0.05 \\
\hline $\mathrm{C}_{4} \mathrm{H}_{10}$ yield $[\mathrm{mmol} / \mathrm{g} \cdot \mathrm{h}]$ & 0.06 & 0.09 & 0.02 & 0.01 \\
\hline $\mathrm{C}_{4} \mathrm{H}_{8}$ yield $[\mathrm{mmol} / \mathrm{g} \cdot \mathrm{h}]$ & 0.11 & 0.17 & 0.02 & 0.01 \\
\hline$n-\mathrm{C}_{3} \mathrm{H}_{7} \mathrm{OH}[\mathrm{mmol} / \mathrm{g} \cdot \mathrm{h}]$ & 0 & 1.50 & 0 & 0.06 \\
\hline $\mathrm{C}_{2} \mathrm{H}_{5} \mathrm{CHO} \quad[\mathrm{mmol} / \mathrm{g} \cdot \mathrm{h}]$ & 0 & 0.28 & 0 & 0.02 \\
\hline
\end{tabular}

introduced into the feed gas.

\section{2. 2. Reactions of Added Ethylene}

As compared in Table 3, ethylene was added to the feed gas as probe molecule to investigate its effects on catalyst reaction. With the $120^{\circ} \mathrm{C}$ calcined catalyst, ethylene was formed from syngas at a rate of $0.02 \mathrm{mmol} / \mathrm{g} \cdot \mathrm{h}$ in the conventional $\mathrm{FT}$ reaction. It was calculated that $81.6 \%$ of the added ethylene reacted, of which, $56.2 \%$ was hydrogenated to ethane while $1.7 \%$ to propionaldehyde and $8.9 \%$ to propyl alcohol. The residual $14.8 \%$ was involved in the chain growth that resulted in increasing formation rates of C3, C4 but decreasing rate of methane formation.

With the $400^{\circ} \mathrm{C}$-calcined catalyst, $95.0 \%$ of the added ethylene reacted; however nearly all of it was hydrogenated to ethane. Only $0.1 \%$ of the added ethylene was converted to propionaldehyde and $0.4 \%$ to proply alcohol. The contribution of the added ethylene to chain growth was not obvious, since there was no change in the chain-growth probability. On either catalysts calcined at $120^{\circ} \mathrm{C}$ and $400^{\circ} \mathrm{C}$, methane selectivity was suppressed by addition of ethylene, probably by the combination of added ethylene and carbene. Carbene was recognized as the precursor of methane.

As will be discussed in detail below, for $120^{\circ} \mathrm{C}$ calcined catalyst, small Ru crystalline can not easily decompose the $\mathrm{CO}$ combination of the adsorbed CO. The hydroformylation reaction that occurred between nondissociative adsorbed $\mathrm{CO}$ and propyl species led to oxygenate formation. But for $400^{\circ} \mathrm{C}$-calcined catalyst, $\mathrm{CO}$ adsorbed dissociatively onto large $\mathrm{Ru}$ crystallines to enhance the chain-growth probability, and the possibility of oxygenate formation was very low.

\section{3. Characteristics of Adsorbed Carbon Mon- oxide}

\section{3. 1. IR Spectra of Adsorbed CO}

High pressure IR was utilized to probe the reaction behavior of syngas and hydrocarbons on Ru catalysts. In Fig. 8 the IR spectra of adsorbed species reacting on the $120^{\circ} \mathrm{C}$-calcined catalyst at $240^{\circ} \mathrm{C}$ are shown. The large absorbance at $2064 \mathrm{~cm}^{-1}$ and $2000 \mathrm{~cm}^{-1}$ should be assigned to the adsorbed CO. Its strength did not change with ethylene introduction. The absorbance peaks at $2978,2958,2878,1476,1447 \mathrm{~cm}^{-1}$ were attributed to the $\mathrm{C}-\mathrm{H}$ bond, and the strengths of these bands increased when ethylene was introduced into syngas, indicating that the added ethylene adsorbed onto the $\mathrm{Ru}$ surface.

As shown in Fig. 8, on the $400^{\circ} \mathrm{C}$-calcined catalyst, the absorbance at $2040 \mathrm{~cm}^{-1}$, which represents the adsorbed $\mathrm{CO}$ on $\mathrm{Ru}$, was very small. This evidence supports the fact that $400^{\circ} \mathrm{C}$ calcined catalyst had a small metal surface and cleaved the $\mathrm{CO}$ bond more easily. Peaks at $2914 \mathrm{~cm}^{-1}$ and $2846 \mathrm{~cm}^{-1}$ represent the $\mathrm{C}-\mathrm{H}$ stretch vibration. Strengths of these peaks were larger than those on the $120^{\circ} \mathrm{C}$-calcined catalyst, for the adsorption of syngas only. This observation is in good accordance with the reaction performance that TOF of CO hydrogenation is higher on the higher-temperature-calcined catalyst. As similar to the case of $120^{\circ} \mathrm{C}$-calcined catalyst, $1474 \mathrm{~cm}^{-1}$ and $1441 \mathrm{~cm}^{-1}$ which appeared after the introduction of ethylene should be considered as brought about by ethylene adsorption.

\section{3. 2. TPR and TPD of Adsorbed CO}

In Fig. 9, the TPR profiles of the catalysts calcined at $120^{\circ} \mathrm{C}$ and $400^{\circ} \mathrm{C}$ are shown. For the $120^{\circ} \mathrm{C}$-calcined catalyst, the main peak of methane formation is located at $160^{\circ} \mathrm{C}$, but it is shifted to $240^{\circ} \mathrm{C}$ for the $400^{\circ} \mathrm{C}$-calcined catalyst. It seemed that the combination between $\mathrm{Ru}$ atom and adsorbed $\mathrm{CO}$ was stronger when the catalyst was calcined at high temperature.

The TPD results shown in Fig. 10 characterize different desorption behavior of the catalysts calcined at different temperatures in air. The desorbed product was $\mathrm{CO}$ formed along with $\mathrm{CO}_{2}$ via disproportionation reaction of the adsorbed CO. It is shown that, for the catalyst calcined at $120^{\circ} \mathrm{C}$, the distribution of the $\mathrm{CO}_{2}$ formed was extended to higher temperatures about to $380^{\circ} \mathrm{C}$. A large amount of $\mathrm{CO}$ could be detected at low temperatures. On the other hand, for the catalyst calcined at $400^{\circ} \mathrm{C}$, the main fraction of the $\mathrm{CO}_{2}$ formed was shifted to lower temperatures and it could not be detected above $300^{\circ} \mathrm{C}$. Meanwhile, the $\mathrm{CO}$ desorbed could not be detected at low temperatures and it was concentrated at above about $200^{\circ} \mathrm{C}$.

Considering the route of $\mathrm{CO}_{2}$ formation in TPD experiments, it seemed that on the $120^{\circ} \mathrm{C}$-calcined catalyst, the adsorbed $\mathrm{CO}$ had a strong carbonoxygen bond and thus a weak metal-carbon bond. Reversely, the adsorbed CO on the $400^{\circ} \mathrm{C}$-calcined 


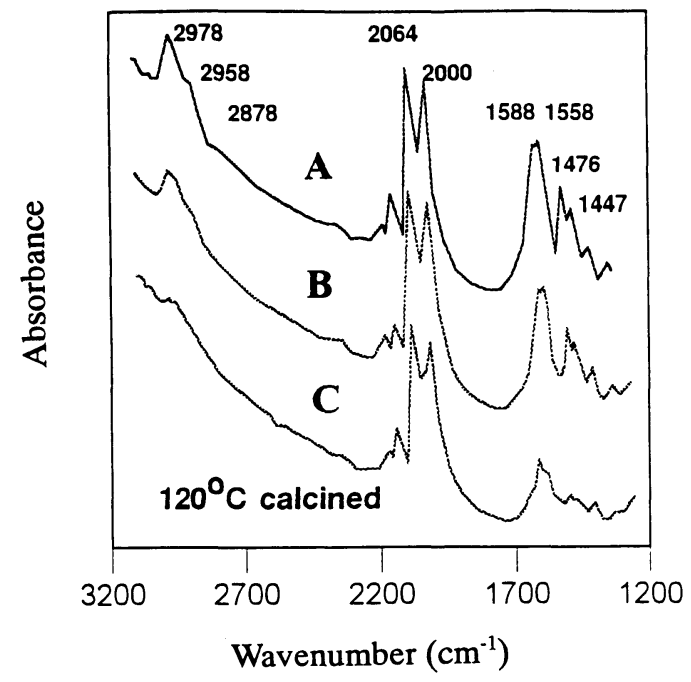

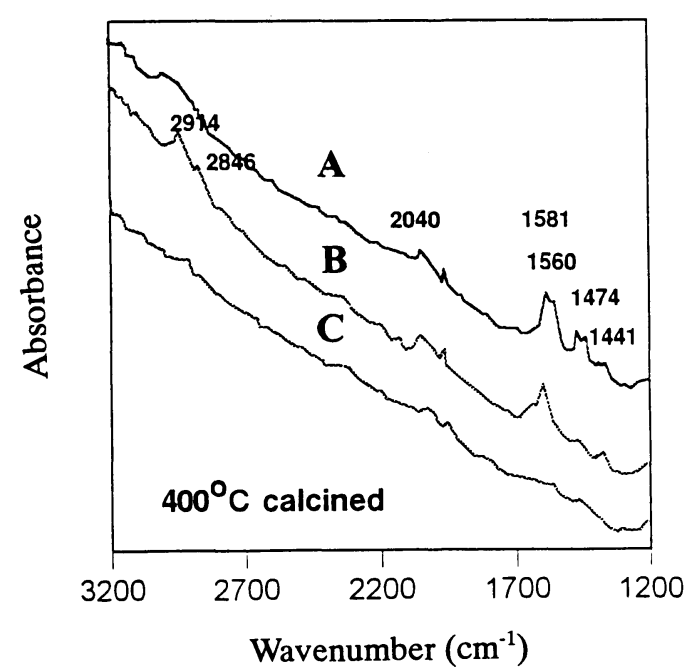

A 5 mol\% $\mathrm{C} 2 \mathrm{H} 4$ after $2 \mathrm{~h}$
B syngas only after $2 \mathrm{~h}$
C Background

Gas phase, $21 \mathrm{~atm}$, flow rate: $40 \mathrm{ml} / \mathrm{min}, \mathrm{H}_{2} / \mathrm{CO}=2 / 1$.

Fig. 8 Comparison of IR Spectra for $2 \mathrm{wt} \% \mathrm{Ru} / \mathrm{Al}_{2} \mathrm{O}_{3}$ Catalysts

catalyst had a tight metal-carbon combination and a loose carbon-oxygen bond.

Much work has been done in correlating the catalytic activity of the FT reaction with the characteristics of different crystallographic planes ${ }^{34)}$. Yokohama et al. ${ }^{35)}$ proved that $\mathrm{CO}$ molecule ad-

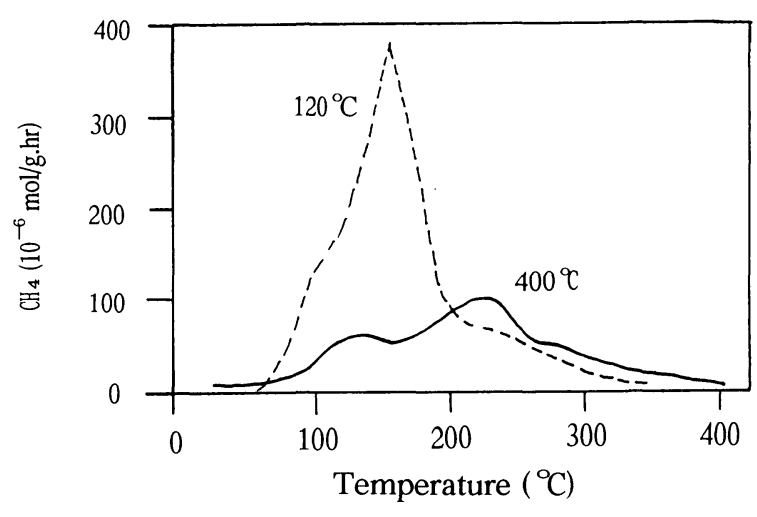

Fig. 9 Temperature Programmed Reaction (TPR) Profiles of Adsorbed $\mathrm{CO}$ on $\mathrm{Ru} / \mathrm{Al}_{2} \mathrm{O}_{3}$ (Aerosil) Calcined at Different Temperature with $6.67 \mathrm{~K}$ / $\min$

$\operatorname{TPD~Ru} / \mathrm{Al} \mathrm{2}_{3}\left(120^{\circ} \mathrm{C}\right.$ calcined $)$

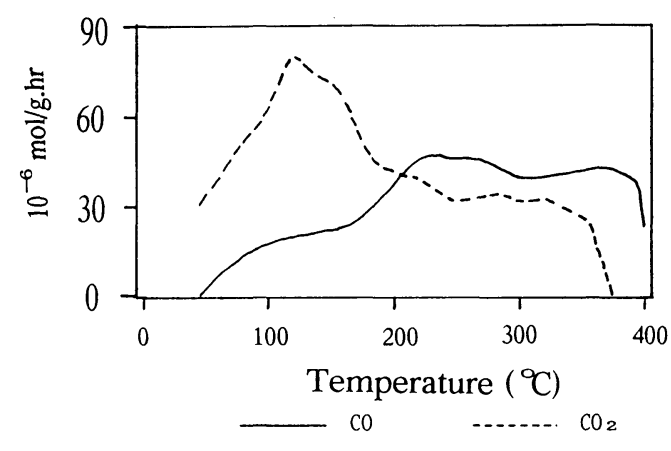

$\operatorname{TPD} \mathrm{Ru} / \mathrm{Al} \approx \mathrm{O}_{3}\left(400^{\circ} \mathrm{C}\right.$ calcined $)$

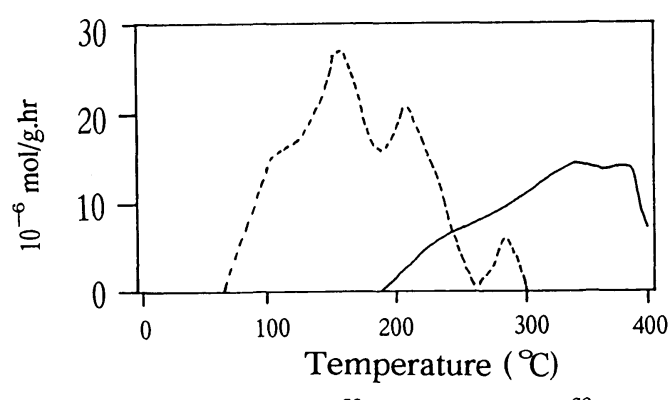

Fig. 10 Temperature Programmed Desorption (TPD) Spectra of Adsorbed $\mathrm{CO}$ on $\mathrm{Ru} / \mathrm{Al}_{2} \mathrm{O}_{3}$ (Aerosil) Calcined at Different Temperature with 6.67 $\mathrm{K} / \mathrm{min}$

sorbed on the incomplete coordination sites of the metal surface, such as steps or kinks on crystalline planes, formed in a linear mode. But on the flat plane of a metal surface, one $\mathrm{CO}$ molecule was readily adsorbed by an assembly of $\mathrm{Ru}$ atoms, resulting in a bridge mode or other mode of combination between carbon and multiple metal atoms. 
It is considered here that carbon monoxide adsorbed on a flat $\mathrm{Ru}$ plane exhibits a strong ruthenium-carbon combination and thus a weak carbon-oxygen bonding, similar to the behavior expected on $\mathrm{Ru} / \mathrm{Al}_{2} \mathrm{O}_{3}$ calcined at $400^{\circ} \mathrm{C}$. The present authors found that on the aluminasupported $\mathrm{Ru}$ catalyst calcined at $427^{\circ} \mathrm{C}$, the bridge-type adsorbed $\mathrm{CO}$ was more active to hydrogenation than the linear-type adsorbed CO and it was the main source of hydrocarbons formed in the usual FT reaction temperature ${ }^{36}$. On the $400^{\circ} \mathrm{C}$-calcined catalyst of large-size crystallites and flat $\mathrm{Ru}$ atom planes, more $\mathrm{CO}$ seems to be adsorbed in the bridge type, and the carbon atom was coordinated by more than one surface $\mathrm{Ru}$ atom. This strong metal-carbon combination structure weakened carbon-oxygen bond and it was readily to cleave because of the electron shift. On the other hand, for $120^{\circ} \mathrm{C}$-calcined catalyst, in which there were more unperfected spots and incomplete coordination surroundings for constructing a linear-type CO adsorption structure, the carbon-oxygen bond was somewhat too strong to be cut off and it was not favorable for hydrogenation, as well as for carbon chain growth, as its reaction performance had indicated.

The TPD results are not contradictory to TPR profiles. The formation of methane from adsorbed CO consisted of two main steps: the cleavage of carbon-oxygen bond and hydrogenation of surface carbide. As shown, the main peak of methane for $400^{\circ} \mathrm{C}$-calcined catalyst was at $240^{\circ} \mathrm{C}$, which was higher than $160^{\circ} \mathrm{C}$ for $120^{\circ} \mathrm{C}$-calcined catalyst. The difference could be attributed to the strong combination of metal-carbon bond on a large, flat $\mathrm{Ru}$ plane in the $\mathrm{Ru}$ crystalline. This type of carbide was difficult for complete hydrogenation to form methane ${ }^{37)}$ but was resultantly favorable for carbon chain propagation to form partially hydrogenated species: $-\mathrm{CH}_{2}-$ or $-\mathrm{CH}_{3}{ }^{-}$. This should be the reason that the carbon chaingrowth probability was so high on the $400^{\circ} \mathrm{C}$ calcined Ru catalyst.

\section{Conclusions}

Calcination temperature in the preparation of catalysts showed remarkable effects on the reaction characteristics by controlling such factors as metal dispersion and structural change.

1) The Fischer-Tropsch synthesis reaction on the alumina-supported ruthenium catalyst was structure-sensitive. The specific activity of large supported $\mathrm{Ru}$ crystalline was somewhat higher than that of smaller one. However, the apparent activitiy of the catalyst calcined at lower tem- peratures was higher due to its high metal dispersion.

2) On the high-temperature-calcined catalysts, the carbon chain-growth probability was higher, and more waxy products remained inside the catalyst bed and reactor. Also, high-temperature-calcined catalysts were favorable for producing more olefins than low-temperature-calcined ones.

3) Addition of water to syngas enhanced the chaingrowth probability as well as the olefin-to-paraffin ratio of the products. For the catalyst calcined at $120^{\circ} \mathrm{C}$, the hydrocarbon yield increased as water gas partial pressure was increased, but the yield decreased slightly when water gas partial pressure was increased for the catalyst calcined at $400^{\circ} \mathrm{C}$.

4) In the ethylene-added FT reaction, oxygenates formed markedly on the $120^{\circ} \mathrm{C}$-calcined catalyst due to the hydroformylation reaction. But this reaction was not observed on $400^{\circ} \mathrm{C}$-calcined catalyst.

5) For the adsorption of $\mathrm{CO}$ on the $\mathrm{Ru}$ site, the metal-carbon bond was stronger on the larger $\mathrm{Ru}$ crystalline while the carbon-oxygen bond became weaker, but on the smaller Ru crystalline, relatively weak metal-carbon combination as well as strong carbon-oxygen bond existed.

\section{Acknowledgments}

The assistance from Ube Industries Co., Ltd. for part of instrumental analysis was greatly appreciated.

\section{References}

1) Dalla-Betta, R. A., Piken, A. G., Shelef, M., J. Catal., 35, 54 (1974).

2) Dalla-Betta, R. A., Piken, A. G., Shelef, M., J. Catal., 40, 173 (1975).

3) Iglesia, E., Soled, S. L., Fiato, R. A., J. Catal., 137, 212 (1992).

4) Iglesia, E., Reyes, S. C., Madon, R. J., J. Catal., 129, 238 (1991).

5) Madon, R. J., Iglesia, E., J. Catal., 139, 576 (1993).

6) Iglesia, E., Soled, S. L., Fiato, R. A., Via, G. H., J. Catal., 143, 345 (1993).

7) Iglesia, E., Reyes, S. C., Madon, R. J., Soled, S. L., Adv. Catal., 39, 221 (1993).

8) Kikuchi, E., Matsumoto, M., Takahashi, T., Machino, A., Morita, Y., Appl. Catal., 10, 251 (1984).

9) Kelzenberg, J. C., King, T. S., J. Catal., 126, 421 (1990).

10) Datye, A. K., Schwank, J., J. Catal., 93, 256 (1985).

11) Peden, C. H. F., Goodman, D. W., Ind. Eng. Chem. Fundam., 25, 58 (1986).

12) King, D. L., J. Catal., 51, 386 (1978)

13) King, D. L., J. Catal., 35, 54 (1978).

14) Kellner, C. S., Bell, A. T., J. Catal., 75, 251 (1982).

15) Kellner, C. S., Bell, A. T., J. Catal., 71, 296 (1981).

16) van Hardeveld, R., Hartog, F., Adv. Catal. Relat. Subjects, 22, 75 (1972) 
17) Smith, K. J., Everson, R. C., J. Catal., 99, 349 (1986).

18) Stoop, F., Verbiest, A. M. G., Van der Wiele, K., Appl. Catal., 25, 51 (1986).

19) Fujimoto, K., Nobusawa, T., Fukushima, T., Tominaga, H., Bull. Chem. Soc. Jpn., 58, 3164 (1985).

20) Fukushima, T., Fujimoto, K., Tominaga, H., Appl. Catal., 14, 95 (1985).

21) Mieth, J. A., Schwarz, J. A., J. Catal., 118, 203 (1989).

22) Fan, L., Yokota, K., Fujimoto, K., AIChE J., 38, 1638 (1992).

23) Yokota, K., Fujimoto, K., Ind.Eng. Chem. Res., 30, 95 (1991).

24) Yokota, K., Hanakata, Y., Fujimoto, K., Chem. Eng. Sci., 45, 2743 (1990).

25) Anderson, J. R., "Structure of Metallic Catalysts," Academic Press, London (1975).

26) Nijs, H. H., Jacobs, P. A., J. Catal., 65, 328 (1980).

27) Poltorak, O. M., Boronin, V. S., Russ. J. Phys. Chem., 40, 1436 (1966).

28) Van Hardeveld, R., Hartog, F., Surf. Sci., 15, 189 (1969).
29) Van Hardeveld, R., Hartog, F., Adv. Catal., 22, 75 (1972).

30) Basset, J. M., Ugo, R., "Aspects of Homogeneous Catalysis,” ed. by Ugo, R., Vol. 3, Reidel, Boston (1977).

31) Abrevaya, H., Cohn, M. J., Targos, W. M., Robota, H. J., Catal. Lett., 7, 183 (1990).

32) Fan, L., Yokota, K., Fujimoto, K., Topics in Catalysis, 2, 267 (1995).

33) Nijs, H. H., Jacobs, P. A., J. Catal., 66, 401 (1980).

34) Vannice, M. A., "Catalysis, Science and Technology," eds. by Anderson, J. R., Boudart, M., Vol. 3, Springer-Verlag, Berlin (1982).

35) Yokohama, A., Komiyama, H., Inoue, H., Matsumoto, T., Kimura, H., J. Catal., 68, 355 (1981).

36) Fujimoto, K., Kameyama, M., Kunugi, T., J. Catal., 61, 7 (1980).

37) Ponec, V., van Barneveld, W. A., Ind. Eng. Chem., Prod. Res. Dev., 18, 268 (1979).

要 旨

\title{
担持ルテニウム触媒を用いる Fischer-Tropsch 合成： 触媒焼成温度の反応挙峌への影翠
}

\author{
範 立, 宮内 理治, 藤元 董 \\ 東京大学工学部応用化学科, 113 東京都文京区本郷 7-3-1
}

アルミナに担持したルテニウム触媒の空気焼成温度が変わる

と，金属分散度など触媒物性が変化したので，担持ルテニウム 触媒を用いた Fischer-Tropsch 合成の反応挙動も大きく変化し た。この反応挙動は低温焼成触媒と高温焼成触媒の二つのパ ターンに分けられる。アルミナに担持したルテニウム触媒上の Fischer-Tropsch 合成反応は構造敏感反応であった。超臨界流 体を用いて反応後の触媒層に残された高分子量炭化水素を抽出 して分析したが，炭素連鎖成長確率とオレフィン/パラフィン
比は金属分散度に大きく依存することが分かった。合成ガスに 水を添加すると，炭素連鎖成長確率とオレフィンの割合は増加 した。一方，合成ガスにエチレンを添加すると，低温焼成の触 媒ではアルコール，アルデヒドなど含酸素化合物の生成が見ら れ，高温焼成の触媒ではこのような含酸素化合物の生成はでき なかった。吸着 CO とルテニウム表面の結合の強さがルテニ ウム粒子のサイズに制御され，反応成績に影響した。

\section{Keywords}

Fischer-Tropsch synthesis, Ruthenium catalyst, Catalyst structure, Calcination, Extraction 